\title{
Assessing Assessment: Toward a Hermeneutic-Phenomenological Perspective
}

\author{
Michael Strawser, PhD \\ Assistant Professor, Department of Philosophy \\ University of Central Florida
}

\begin{abstract}
Assessment is generally not a favorite subject for many teachers, and this is likely due to a perceived tension between the goals they wish to accomplish as educators and the methods of assessments prescribed by accrediting agencies. With even President Obama calling for improvements in assessing education, this paper seeks to develop an innovative phenomenological-hermeneutic model of assessment, one that focuses on the first-person interpretation of one's transformative educational experience. After the theoretical framework for developing this model is explained, I present an application of the model through the introduction of "mindful reading assignments."
\end{abstract}

\section{Introduction}

It would seem that, as a rule, philosophers are not particularly fond of assessment. Without wishing to incriminate my colleagues or myself, I take this as a general observation. Perhaps supporting evidence can be found in the following experience: At a recent divisional meeting of the American Philosophical Association with 1,008 members listed as participants, how many do you think attended a group session sponsored by the American Association of Philosophy Teachers devoted to the topic of assessment in Philosophy Courses? ${ }^{1}$ As it turned out, I was one of two members of the audience, and awkwardly, the other member snuck out towards the end of the first presentation, while I remained. What's wrong with the topic of assessment? Why is there such a low level of engagement? Is it because any reflection on teaching and testing is at best secondary to the main pursuit of wisdom? True, Socrates disavowed being a teacher and had seemingly little interest in assessing his disciples. If anything, he reasoned, they should assess

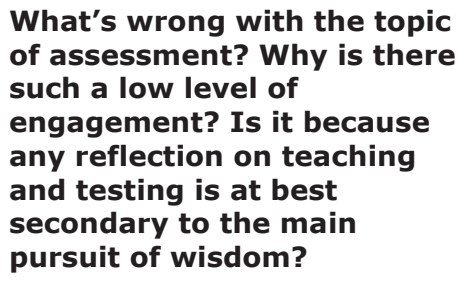
didn't have in mind that students should be subject to repeated standardized examinations. $^{3}$ Indeed, it is difficult to imagine Socrates fitting into our higher education system today, but perhaps this reasoning for the lack of interest in assessment is a bit too idealistic.

It is somewhat comforting to note that it is not only philosophy teachers who feel and think this way. As noted in a meeting I attended in the fall semester of 2008 at the Faculty Center for Teaching and Learning (FCTL) at the University of Central Florida, "work with assessment [is] most of the time [work with] a hostile audience," and "you're not supposed to be grumpy unless you're talking about assessment." I admit that these reflections generally fit with my own experiences in working on our General Education Program (GEP) assessment and trying to get others interested in the process. Why all the grumpiness? If it is not because that we are solely interested in the isolated pursuit of truth in itself, is it rather that we are quite suspicious that common assessment models involving standardized direct measures fail to account for the whole learning experience in all its complexity? ${ }^{4}$

Even our nation's President is concerned about assessment. From the campaign trail in New Hampshire in November 2007 to March $10^{\text {th }}, 2009$, when he unveiled his specific proposals for public education, President Obama has repeatedly called for "innovative assessments" (2007, p. 8). ${ }^{5}$ Although focused primarily on K- 
12 education and skill-based learning, Obama has clearly suggested that we need to develop alternative assessments that encourage our students "to become more than just good test-takers" and "that don't just test isolated bits of information" (p. 8). In his most recent speech, Obama called on education chiefs to develop "assessments that don't simply measure whether students can fill in a bubble on a test, but whether they possess $21^{\text {st }}$ century skills like problem-solving and critical thinking, entrepreneurship, and creativity" (2009, para. 23). ${ }^{6}$ Thus the time is ripe for thickening the discussion of assessment.

When we focus on higher education, however, where our goal is to educate and not merely train our students, we must be wary of the move to more standardized, "direct" measures of quantifiable "outcomes." Dean Adam Falk of Johns Hopkins University expressed his concern that assessment practices focused "on standardization and quantification will impel us to an impoverished vision of higher education that would do our nation a profound disservice" (2008, para. 5). ${ }^{7}$ The reasoning behind this claim is based on a vision of the university that is centered on the goal of developing character and invigorating "the intellectual and moral forces," as well as Falk's discussions with alumni who only gain a clearer understanding of the significance of their education years after they have graduated. Thus Falk opposes the "new standardized testing regime" because it is clear that "a single test cannot uniformly evaluate the quality of the student experience, and the essential 'value added' of an education is not largely revealed by graduation" (para. 6). What is perhaps most important for this article is that Falk's comments emphasize the importance of focusing on the significance of the educational experience as a whole and not on particular bits of knowledge or skills. ${ }^{8}$

An even deeper worry is expressed by the holistic educators Sharon Solloway and Nancy Brooks (2004), who suggest that the "standardization and instrumental application of knowledge is akin to violence," (p. 43) ${ }^{9}$ and they call, following Paul Ricoeur, "for the necessity of a constant watchfulness for the ways our own pre-conceived notions deform our understanding and reception of other texts, ideas, objects and/or persons" (p. 43). "We cannot," they note, "underestimate the subtle nature of this violence to deceive us into complacency" (p. 43). So, at the very least, we need to reflect on our assessment measures and be aware of the potential for violence (i.e., forcing students to think about a question in one particular way and to confine their answer, for example, to a limited number of multiple choice or rubric options).

In this article, I reflect on my current Scholarship of Teaching and Learning (SoTL) project ${ }^{10}$, aiming to extend the discussion initiated by Solloway and Brooks (2004) in their paper, "Philosophical Hermeneutics and Assessment." Here they offer a new model of assessment based on Hans-Georg Gadamer's (1989) work, in particular his understanding of experience as Erlebnis and Erfahrung. I shall explain this model and attempt to add phenomenological support for it, and then consider how it might be applied in philosophy and humanities classes through the introduction of "mindful reading assignments." Finally, I shall briefly consider the potential benefits of this model of assessment, as well as the nature of "mindfulness."

\section{Phenomenology and Education}

The central subject matter of phenomenology is experience. "Phenomenology is concerned with attaining an understanding and proper description of the experiential structure of our mental/embodied life" (Gallagher \& Zahavi, 2008, p. 9). A phenomenological assessment will thus focus on the experience of the learner, the "how" of the experience more than the "what." 
Further, all experience involves perception, and phenomenologists appear to be agreed that all perception "involves an interpretation"; one does not simply receive information in perception (Gallagher \& Zahavi, 2008, p. 9). Consequently, a "direct" measure of learning from a phenomenological perspective would involve an analysis of the first-person perspective, and a third-person, objective perspective would be considered derivative or indirect. This is a curious reversal of the common assessment practices promoted by accrediting agencies today that emphasize the use of so-called "direct" measures of learning designed to eliminate the perceptions of the learners.

Let me explain further and try to preempt a possible misunderstanding. Although phenomenologists promote the investigation of the first-person perspective associated with human subjectivity, it would be mistaken to consider this approach as either introspective or subjective. From phenomenology's beginning in the writings of the founder Edmund Husserl (1859-1938) there has been a consistent attempt to dissociate this method from introspective psychology ${ }^{11}$ and to explain how it is not based on subjectivism. ${ }^{12}$ Thus only by misunderstanding the phenomenological method could one think that any assessment derived from it would be a promotion of individualistic, subjective feelings.

It is also important to acknowledge that Husserl and later phenomenologists, such as Martin Heidegger (1889-1976) and Hans-Georg Gadamer (1900-2002), clearly do not reject objective, scientific knowledge. Rather, they attempt to understand how such knowledge is constituted, and it is precisely the recognition that objective knowledge is a derivative phenomenon which shows the limitations of the objective, third-person perspective. In other words, that which is perceived (i.e., interpreted) as "objective" is done so by someone for someone within a larger framework of significance and purpose. In

It seems to be more often the case than not that when assessing students we are looking for evidence of new facts, knowledge, and/or skills, rather than an experience of personal growth and transformation gained through engaging in a dialogue. short, phenomenologists have sought to understand this larger framework, which is referred to as the "life-world" in Husserl, "being-in-the-world" in Heidegger, and the "hermeneutical situation" in Gadamer. Any assessment practice based on a phenomenological method-which would also embrace a hermeneutical approach ${ }^{13}$-would thus attempt to incorporate an appreciation of this larger framework and the "constitution" ${ }^{14}$ of knowledge.

\section{Hermeneutics and Assessment}

The subtitle of Solloway and Brooks' (2004) paper on "Philosophical Hermeneutics and Assessment" is "Discussions of Assessment for the Sake of Wholeness," and in the introduction their aim is clearly stated: "We seek a healthier model, with greater possibilities for assessment that nourishes wholeness" ( $p .43$ ). In contrast, positivistic models based on "the traditional notion [that] the transmission of knowledge is evidence of learning" are less healthy and humane, because they are "designed to eliminate a student's particular history of being" and silence his or her voice (p. 44). While there are certainly exceptions in assessment practices which do allow for the student's understanding and history of being to be included (such as in portfolios), it does seem to be more often the case than not that when assessing students we are looking for evidence of new facts, knowledge, and/or skills, rather than an experience of personal growth and transformation gained through engaging in a dialogue. For Solloway and Brooks it is such an experience that allows for "the possibility of evolving wisdom and compassion" ( $p$. $45)$. Without providing evidence for this profound claim at this point in their article (although I think some may possibly be found in an examination of the written student reflections they later cite), Solloway and Brooks turn their discussion to 
Gadamer and the consideration of experience given in the German terms Erlebnis and Erfahrung.

Before explaining this distinction, it is important to note the following points, which are not addressed by Solloway and Brooks. First, Gadamer's understanding of the hermeneutical process is grounded in Heidegger's analysis of understanding expressed in sections 31 and 32 of Being and Time (1927), which describes understanding as an existential mode of being that prefigures knowing and asserting. Second, in Gadamer's defining study Truth and Method, it is clear from the outset that he is not arguing for one conception of truth and one conception of method, and consequently he is not rejecting scientific "truth" and method, the extended development of which may lie behind the current positivistic tradition of assessment in what has been called "the Age of Accountability." 15 For there are learning processes characterized by the acquisition of knowledge and skills, and thus there may be assessment models suited for these processes. Gadamer (1989) would have us see, however, that "there is an experience of truth that transcends the domain of the scientific method" ( $p$. xxi). This is the truth experienced in the phenomenon of understanding, the investigation of which is the central focus of Gadamer's entire study. For example, in the experience of understanding a work by Plato, Spinoza, or Hegel, "a truth is known that could not be attained in any other way, even if this contradicts the yardstick of research and progress by which science measures itself" (p. xxi). ${ }^{16}$ In other words, "truth" in this sense is not a skill or craft (technē) or the correct conformity between the idea and the object (adequatio), but rather the unveiling (alētheia) of being in the selfunderstanding of the seeker. Heidegger, in particular, has emphasized this understanding of truth and its genuine association with education (paideía). This is summarized nicely in Shaun Gallagher's Hermeneutics and Education:

...then knowledge, in Plato's sense, is not a matter of adequatio but of alētheia. Adequatio is taken as an inadequate kind of truth. It does not constitute the truth that must be sought in the educational process. For Plato, education means always going beyond truth as adequatio. Adequatio is a characteristic of purely technical or intellectual-logical, mathematical, formalknowledge, a knowledge that lacks a moral dimension, a cleverness without phronēsis [practical wisdom]. Plato is not ambiguous about this. Education cannot be reduced to technē or adequatio. It involves more than a literacy with respect to correct opinions. It involves a self-knowledge that changes the learner. (p. 200) ${ }^{17}$

In light of this richer understanding of the nature of education, which is irreducible to technē or adequatio, it becomes evident that our assessment practices need to be enriched to account for the nature of truth as alêtheia. Thus, we must realize that there are experiences of learning that transcend traditional assessment practices. Such experiences may be more obvious in the arts and humanities, which in turn would be the disciplines most in need of alternative models of assessment. But here it should be noted that in Truth and Method it was not Gadamer's (1989) concern to establish a new method or system of rules on how we should proceed. Rather, he states: "my real concern was and is philosophic: not what we do or what we ought to do but what happens to us over and above our wanting and doing" ( $p . x x v-x x v i)$.

Let us now consider the complex distinction between Erlebnis and Erfahrung, which for Solloway and Brooks (2004) lies at the heart of their new holistic thinking on assessment. They begin their discussion as follows:

While traditional notions of learning and assessment [consider/as] a replication and/or application as evidence of having mastered a pre-given body of knowledge, Erlebnis and Erfahrung may be associated with a philosophical hermeneutical notion of

InSight: A J ournal of Scholarly Teaching 
assessment as an aesthetic experience - one in which the individual encounters him/herself and engages in a play across horizons. (p. 45)

I would offer that it is rather rare that we consider assessment as an aesthetic experience, and I would like us to keep this idea in mind, while taking both "aesthetic" and "experience" in the broadest senses. ${ }^{18}$ For Gadamer, it seems, the aesthetic experience par excellence is an engagement with a literary text, ${ }^{19}$ and surely any course offered at the university, whether science or humanities, is going to include this experience. It will also include the aesthetic experience of engaging the oral tradition given through the language of the instructor, so "aesthetic assessment" may be applicable to all disciplines.

Although "Gadamer typically uses the term Erlebnis with a critical overtone, and the term Erfahrung with a positive one" (1989, p. xiii), Solloway and Brooks (2004) argue for an interpretation that brings together both notions of experience. They take Erlebnis to define an immediate, particular experience that jolts one "out of the ordinary" and "awakens us to ourselves in a way that we haven't been awakened before" (p. 46). In contrast, Erfahrung "is a way of being, a stance or orientation to experience in general" (p. 46). In other words, we might say that Erlebnis is a subjective event, "it is all about ME; it happens TO me" ( $p$. 46). Erfahrung moves beyond subjectivity to an understanding that is radically undogmatic, one in which I understand my experiences not as "isolated moments, but an ongoing integrative process in which what we encounter widens our horizon" (Gadamer, 1989, p. xiii). For Gadamer, "the dialectic of experience has its proper fulfillment not in a definitive knowledge but in the openness to experience that is made possible by experience itself" (p. 355). It would seem, then, that this openness to ever-widening horizons allows for the possibility of transformation, in which one transcends one's isolated subjectivity-but one does not eliminate it-to become an integrated part of the whole.

\section{Theory in Practice: Mindful Reading Assignments}

"What assessment practices might be invented by teachers who are interested in drawing students toward their own hermeneutic imagination?...toward their own growth in appreciation of the wholeness and integrity of the world?" (Solloway \& Brooks, 2004, p. 50). This is the question posed by Solloway and Brooks, and answered by the different model of assessment they propose, one that does not eliminate "the idiosyncrasies of personal relevance, cultural context, and historical context," but rather allows "students to bring their personal histories to the table" (p. 51). The assessment designed by Solloway is a "self-evaluation" assessment of learning, which is claimed to have "demonstrated a texture of 'mindfulness'” (p. 58).

The merit of this initiative lies in its innovative use of philosophical hermeneutics as a model of assessment. It opens assessment to the possibilities of a holistic notion of mindfulness - observing the mind in its processes. Perhaps, this accounts for the responses that describe learning as if it is a new experience. Mindfulness practitioners often describe ordinary experience as having a keenness - a sense of vibrancy not noticed without mindfulness. (p. 58)

Following this initiative, I have designed what I call "Mindful Reading Assignments" for my Introduction to Philosophy classes, and have just begun asking my students to complete them during the 2008-2009 academic year. A short description of the Mindful Reading Assignment (MRA) is this:

Throughout the course students will be required to submit four MRAs in which they (1) identify a passage from an assigned reading that has affected (deepened, qualified, confirmed, raised new questions, etc.) the way they think and (2) explain the 
significance of the passage (e.g., its difficulty, originality, insight, truthfulness, etc.) and how their thinking has been affected (deepened, qualified, confirmed, raised new questions, etc.). The assignments should include the passage and reference (singledspaced, use ellipses if more than 50 words) and the explanation (double-spaced, 250 to 500 words).

The focus of this assignment is not on demonstrating knowledge about the content or argument found in a particular text (although this inevitably happens along the way), but rather in demonstrating that one has been open to letting the other (in this case the text) engage oneself, and has been transformed through an interpretation of both oneself and the text. In Gadamerian terms this would exhibit a "kind of play, a back and forth or to and fro movement" (Solloway \& Brooks, 2004, p. 45) that is the unveiling or truth of being, which is not entirely objective (since the focus is not on getting the text right) or entirely subjective (since the focus is not solely on what the student thinks alone). Rather the focus is on the encounter in which the object and subject

The focus of this assignment is not on demonstrating knowledge about the content or argument found in a particular text, but rather in demonstrating that one has been open to letting the text engage oneself, and has been transformed through an interpretation of both oneself and the text.

become merged, and both are transcended in the process, that is, in the experience. How exactly this happens through the activity of reading might be considered in some sense "miraculous," ${ }^{20}$ and yet Gadamer's ontological explanation of the work of art goes a long way in clarifying this "miracle." As Gadamer understands it, the concept of play is the clue to the ontological explanation. This means that the mode of being of play helps us to understand the mode of being of the work of art, which "is not an object that stands over and against a subject for itself" (p. 103). Instead,

the work of art has its true being in the fact that it becomes an experience that changes the person who experiences it. The "subject" of the experience of art, that which remains and endures, is not the subjectivity of the person who experiences it but the work itself. (p. 103)

From this line of thought one may understand that when we attempt to assess the student's experience of the work of art by focusing on the changes undergone, we are also assessing the work of art itself understood as experience. For perhaps the most significant part of Gadamer's work in understanding the process of understanding and interpretation-at least if one considers that it is the part most often anthologized-readers should turn to the first section of "Elements of a Theory of Hermeneutic Experience" in which the hermeneutic circle and the conception of prejudices are explained. Relevant to the current discussion is this description of the hermeneutical circle:

The circle, then, is not formal in nature. It is neither subjective nor objective, but describes understanding as the interplay of the movement of tradition and the movement of the interpreter. The anticipation of meaning that governs our understanding of a text is not an act of subjectivity, but proceeds from the commonality that binds us to the tradition. (p. 293) ${ }^{21}$

In an attempt to apply these theoretical concerns to the assessment process, the plan for my SoTL project is to compare classes which are asked to complete MRAs with those that are not, and to see what, if any, significant differences emerge. My expectation would naturally be that the use of MRAs would lead to an enhanced learning experience that would also result in improved results on other more traditional assessments, such as multiple choice and short answer tests. I am also interested in surveying students to find out which method of assessment they find most valuable, but here I am not sure what to expect. Students who are used to traditional assessment measures may not think that the 
MRAs reflect significant learning. This, of course, is yet to be determined, since I am only at the beginning of my study using the intervention of MRAs as an alternative assessment model. Whether the results will provide "an opening for transformation" as presented by Solloway and Brooks (2004) remains to be seen, as also whether it will be possible to categorize the student responses by the following six themes: "new energy/excitement for learning, new visions of how they want to enact teaching and learning, new ways of being in the world, new wisdom about themselves, new experience of learning, [and] concrete horizons" (p. 52). ${ }^{22}$

\section{Conclusion: In Media Res}

The major goals of this paper have been to provide a theoretical background for my SoTL project and a description of the new application of MRAs. Thus my study is "in the middle of things," as all data has not yet been collected, and the data that has been collected does not represent two comparable courses which would yield statistically significant results. I nitially, due to my class schedule, the study focused on two different sections of PHI 2010, Introduction to Philosophy. Group 1 consisted of 18 honors students in the fall semester of 2008, and Group 2 consisted of 75 general students in the spring semester of 2009 . Both groups had the same reading material from Plato, Spinoza, Kierkegaard, and Nietzsche, while Group 1 was asked to complete four "mindful reading assignments" throughout the course and Group 2 was not. Both groups also took the same three tests containing multiple choice, true/false, and essay questions. ${ }^{23}$

Initially, it appeared that students in Group 1 were more comfortable writing expository or reflective pieces, rather than being able to describe their reading experiences and how their thinking was changed in the process. This is reflected in $56 \%$ of the class earning full credit for the first two MRAs compared to $67 \%$ earning full credit in the last two MRAs. As suggested above, the goal of these assignments is neither a straightforward exposition of the text (this would be the predominantly objective focus) nor a personal explanation why a student liked a particular passage (this would be the predominantly subjective focus), but rather a careful

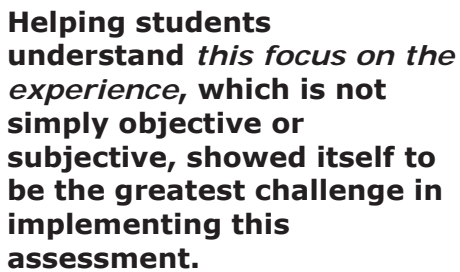

description of how a student's consciousness has been changed in the experience of reading the text. Helping students understand this focus on the experience, which is not simply objective or subjective, showed itself to be the greatest challenge in implementing this assessment. Students needed to be reminded to attempt to express directly how they thought about a particular issue prior to reading the text and how they then thought about it after reading the text. In doing this students were being asked to come to self-knowledge about their own being-in-the-world, and the greatest aid to students in this regard was to read to the class those MRAs that succeeded best in achieving the goals of the assignment.

It does seem that students in Group 1 were satisfied with the MRAs as a method of assessment. In the free response section of the student perception of instruction forms, 11 of 14 students $(79 \%)$ responded favorably to the question: "What is your reaction to the method of evaluating your mastery of the course?"24 Although the majority of comments received were rather general (such as "grading was fair") and this question refers to all assessment measures including tests (which was interestingly the only measure receiving negative comments, while there were no negative comments regarding the MRAs), three students (21\%) commented positively and without any prompting regarding the MRAs in particular. One student even put down "MRAs" for "The thing(s) I like the MOST about this course," and another student wrote: "I enjoyed the required reading and believe the assignments in the class helped me to better understand the material." Further, the following 
unsolicited message from a student in Group 1 was received about a third of the way through the course. This message speaks for itself:

Professor Strawser,

I am participating in the 40 day challenge "Yes, I Believe in God." Today's daily "challenge" is to write a letter of appreciation to someone with general authority over us. I just wanted to thank you for being so open minded with our Intro to Philosophy class and for actually caring about what we think. Many teachers only expect you to read the information and complete the assignment. By giving us the "Mindful Reading Assignments" you are proving to the class that you actually do care about how the course is affecting us. That is more than just working for your paycheck. While, to you, these mindful reading assignments seem like trivial pieces of work that every class should instate, the truth is that many professors don't care about their students as individuals. Thank you again.

Whatever the outcome of a statistical survey of the data, this study has been significant because I have become more mindful of my own assessment practices as a teacher and more open to letting myself be transformed by the students' observations. The MRAs have already provided a pedagogical benefit in that they allow students to determine which passages they find significant rather than the ones I (and the tradition I am following) find significant, and when these passages become the focus of our discussion and analysis, or when the students' reflections provide new questions for their own research papers (which I suspect will happen), it broadens the horizons of us all. Thus I am already starting to realize that using a phenomenological-hermeneutic model of assessment may also provide the opportunity for transformation that Erfahrung offers for the teacher.

\section{Notes}

${ }^{1}$ The actual topic title was "Non-traditional Assessment in Philosophy Courses," but I do not think that the demonstrated lack of interest was due to the "nontraditional" aspect of the topic, but rather to the topic "assessment" itself. Proceedings and Addresses of the American Philosophical Association 81.3 (J anuary 2008): 71. I have since been assured by colleagues in other disciplines that the general lack of interest in assessment is not unique to philosophy and philosophers.

${ }_{2}$ Apology 38a. See Plato, The Last Days of Socrates, edited by Harold Tarrant and translated by Hugh Tredennick (New York: Penguin Classics, 2003).

${ }^{3}$ While Socratic teaching methodology has been much discussed throughout the ages, little, if any, attention has been given to the question of what might be involved in a Socratic approach to assessment. What would appear to be the popular Socratic form of assessment would be oral interviews subject to crossexamination or critical scrutiny (elenchus), but although a consistent method, this would hardly be akin to the kind of standardized practices we have today. It is interesting to note that this kind of assessment prioritizes speech over reading and writing, and that in the Phaedrus Socrates actually argues "that reading and writing are dangerous to learning and thinking," a view which few, if any, educators would agree with today. See David Kallack, "The Speakerly Teacher: Socrates and Writing," Metaphilosophy 20.3 \& 4 (July/October 1989): 341.

4 This is much more than a suspicion for philosophy professor Ken Buckman, who argues quite strongly that "standardized testing is among the worst things one can inflict on education," and that "when we view education merely as an outcome, the real, transformative character of education as process toward intellectual independence is lost." Ken Buckman, "What Counts as Assessment in the $21^{\text {st }}$ Century?" Thought and Action: The NEA Higher Education Journal (Fall 2007): 2931. Accessed at http://www2.nea.org/he/heta07/images/2007pg29.pdf, May 29, 2009.

InSight: A J ournal of Scholarly Teaching 
${ }^{5}$ Barack Obama, Speech on "Our Kids, Our Future," delivered in Manchester, New Hampshire, on November 20, 2007. Accessed at http://www.usatoday.com/news/pdf/obama-on-education-nov-20-2007.pdf, March 13, 2009.

${ }^{6}$ Barack Obama, "Remarks by the President to the Hispanic Chamber of Commerce on a Complete and Competitive American Education," Washington, D.C., March 10, 2009. Accessed at http://www.whitehouse.gov/the_press_office/Remarks-of-thePresident-to-the-United-States-Hispanic-Chamber-of-Commerce/, May 29, 2009.

7 Adam Falk, "Assessing Assessment," Johns Hopkins University Arts \& Sciences Magazine Online 6.1 (Fall 2008), Accessed at http://krieger2.jhu.edu/magazine/f08/view.html, March 13, 2009. The title of my article, a version of which was presented under the same title at the Engagement in Undergraduate Research: Florida Statewide Symposium, University of Central Florida, September 26, 2008, was formulated prior to my knowledge of Falk's article.

8 This should not be taken as denying an imperative of knowledge and the importance of developing particular skills, just that this does not encapsulate the entire mission of university educators.

9 Sharon G. Solloway and Nancy J. Brooks, "Philosophical Hermeneutics and Assessment: Discussions of Assessment for the Sake of Wholeness," Journal of Thought 39.2 (Summer 2004): 43. Although not explicitly developed or analyzed, the background for this seemingly extreme view is to be found in Paul Ricouer's essay, "Violence and Language," in Political and Social Essays, edited by David Stewart and Joseph Bien (Athens: Ohio University Press), 88-101. In this text, Ricouer seeks "to take the largest view of the realm of violence" that moves beyond "a very limited and very reassuring idea of violence" (murder and natural destruction) and considers the problem of violence in relation to language (88-89). In considering various manifestations of violence, Ricouer writes:

There is finally the violence of the always premature conclusion: philosophy exists only in books which are always a finite work of the mind. Books are always brought to a close too quickly, intercepting the process of totalization in an arbitrary termination. This is why all philosophies are particular even though everything is to be found in any great philosophy. And as I am myself one of the violent particularities, it is from my particular point of view that I perceive all these total particularities that are also particular totalities. The hard road of the "loving struggle" is the only road possible (96-97).

Here one may begin to understand how adopting any one particular modality of discourse-such as one implicit in any single, standardized test-will have a totalizing effect on the meaning of the discourse, such that only that discursive practice which fits within the context of the test is meaningful, and all other practices are excluded. Although what may be involved in the "loving struggle" that Ricouer identifies is somewhat vague, it would surely involve "respect for the plurality and diversity of languages," which is what it means "to be non-violent in discourse" (101). As we shall see below, the particular assessment that I have developed seeks to respect the plurality and diversity of the hermeneutical experiences of students in engaging with the philosophical tradition .

10 This project was sponsored by The Karen L. Smith Faculty Center for Teaching and Learning at the University of Central Florida, and I would like to thank the interim director, Dr. Tace Crouse, and the staff of FCTL for their support for this project.

11 "Indeed, all the major figures in the phenomenological tradition have openly and unequivocally denied that they are engaged in some kind of introspective psychology and that the method they employ is a method of introspection." This 
clear statement is supported by significant evidence in Gallagher and Zahavi, The Phenomenological Mind (New York: Routledge, 2008), 21.

12 Husserl remarks that "mere subjectivity should not be confused (as it is so frequently) with an experiential subjectivity, as though the perceived things in their perceptual qualities were themselves experiences..." Edmund Husserl, Ideas: General Introduction to Pure Phenomenology, translated by W. Boyce Gidson (New York: Macmillan Publishing Company, 1962), 158.

13 Readers should keep in mind that phenomenology and hermeneutics are inextricably linked, and I have often thought that it would be useful to come up with a term that refers to both approaches, but somehow "phermeneutics" or "phenomenuetics" seem unsatisfactory. One of the best discussions of the relationship between phenomenology and hermeneutics can be found in Hermeneutics and the Human Sciences by Paul Ricouer, who attempts to make explicit the "mutual belonging" between phenomenology and hermeneutics. According to Ricour, "phenomenology remains the unsurpassable presupposition of hermeneutics. On the other hand, phenomenology cannot constitute itself without a hermeneutical presupposition." Paul Ricoeur, Hermeneutics and the Human Sciences, edited and translated by John B. Thompson (Cambridge: Cambridge University Press, 1981), 101-102.

${ }^{14}$ The notion of "constitution" is very important in Husserl's writings and "expresses the manner in which objects of consciousness come to have the kinds of 'sense and being' that they do, the manner in which subjectivity carries out its function of giving sense." Dermot Moran, Introduction to Phenomenology (London: Routledge, 2000), 164-165.

${ }^{15}$ I don't pretend to know fully the historical reasons behind assessment having become "a national movement with a reform agenda" and what is driving the accrediting agencies that are driving the accredited institutions. (Although I might speculate that the focus on direct measures and positivistic approaches would be connected to "the methodical spirit of science" that "permeates everywhere" today [see Gadamer's Truth and Method, xxvi].) According to Barbara E. Walvoord and Virginia Johnson Anderson, "Faculty are going to have to make peace with this [new] paradigm [of assessment] and with the need to communicate to outsiders in new ways about student learning." Effective Grading: A Tool for Learning and Assessment (San Francisco, CA: Jossey-Bass, 1998), 3.

16 Gadamer, Truth and Method, xxi. This experience is surely not limited to philosophical texts, but is to be found in all works of art.

17 Shaun Gallagher, Hermeneutics and Education (New York: State University of New York Press, 1992), 200. Although the topic of assessment is not directly addressed, Gallagher's far-reaching work presents a detailed consideration of a moderate hermeneutical theory of education.

${ }^{18} \mathrm{I}$ am also reminded of the meeting I attended on "Non-traditional Assessment in Philosophy Courses," where one presentation by Debby Hutchins entitled "Learning as Constructing: Logic Art as Pedagogy" exhibited students' works of art containing logical proofs. See note 1 above.

${ }^{19}$ Gadamer's work clearly prioritizes the notion of text as written, as evidenced in this passage which explains the profound uniqueness of the engagement with a written text.

At any rate, it is not by chance that literature is the place where art and science merge. The mode of being of a text has something unique and incomparable about it. It presents a specific problem of translation to the understanding. Nothing is so strange, and at the same time so demanding as the written word. ...Nothing is so purely the trace of the mind as writing, but nothing is so dependent on the understanding mind either. In deciphering and interpreting it, a miracle takes place: the transformation of something alien and dead into total contemporaneity and 
familiarity. This is like nothing else that comes down to us from the past. The remnants of past life-what is left of buildings, tools, the contents of graves-are weather-beaten by the storms of time that have swept over them, whereas the written tradition, once deciphered and read, is to such an extent pure mind that it speaks to us as if in the present. That is why the capacity to read, to understand what is written, is like a secret art, even a magic that frees and binds us. In it time and space seem to be superseded. People who can read what has been handed down in writing produce and achieve the sheer presence of the past (Truth and Method, 156).

${ }^{20}$ See the passage in the previous note where Gadamer refers to the act of reading as involving a miracle.

${ }^{21}$ Readers familiar with Louise Rosenblatt's transactional theory of the literary work may notice an affinity between Rosenblatt's perspective and Gadamer's, for both writers focus their theories on the experience of the work of art as an event, rather than on the author or the text itself. In Literature as Exploration (1938) Rosenblatt analyzes "The Literary Experience" (Chapter 2) and argues that "the teacher's task is to foster fruitful interpretations-or, more precisely transactions-between individual readers and literary works." I think it is fair to say that both authors are concerned with what Rosenblatt refers to as "the uniqueness of the transaction between reader and text" (which may be related to Gadamer's notion the historicity of the understanding), and that this concern, as Rosenblatt puts it, "is not inconsistent with he fact that both elements in this relationship [reader and text] have social origins and social effects" (which would be captured by Gadamer's understanding of everything that belongs to "tradition"). See Louise M. Rosenblatt, Literature as Exploration, $4^{\text {th }}$ ed. (New York: The Modern Language Association of America, 1978), 26-27. Further agreement may be found in understanding the reader as "productive" or "creative" in the interpretative process, and of particular interest in this context is Rosenblatt's focus on experience. She explains the value of literature "as a means of enlarging [students'] knowledge of the world, because through literature [students] acquire not so much additional information as additional experience. New understanding is conveyed to them dynamically and personally. Literature provides a living-through, not simply knowledge about" (Literature as Exploration, 38, author's italics).

It is rather surprising that there has been little if any discussion of the relationship between these theories and neither Gadamer nor Rosenblatt, as far as I can tell, acknowledges the other's work in their texts. Rosenblatt, however, admits that she was not interested in the phenomenologists (she only mentions Husserl by name and seems to consider all of phenomenology as tainted by idealism, which is surely an unfair criticism of Heidegger, Gadamer, Ricouer, and several other major phenomenologists), perhaps because she had been so taken by the pragmatists, in particular the work of J ohn Dewey. See Louise M. Rosenblatt, The Reader, the Text, the Poem: The Transactional Theory of the Literary Work (Carbondale, Illinois: Southern Illinois University Press, 1978), xiv. The first chapter of this later work deals with "The Poem as Event," and offers the following key passage which fits nicely with Gadamer's understanding: "The poem, then, must be thought of as an event in time. It is not an object or an ideal entity. It happens during a comingtogether, a compenetration, of a reader and a text" (The Reader, the Text, the Poem, 12).

22 Solloway and Brooks studied students taking an undergraduate teacher education required course, and while all significant, I find Solloway and Brooks explanation of the first category-"New Energy/Excitement for Learning"-to be particularly exciting as it parallels some of the responses that I expect to emerge from my study. They explain: 
At the beginning of the semester, many of the students expressed anxiety at being in charge of selecting what would count as learning for them from the assigned readings. (...) It was hard for these students to "think" about their learning, to think about how the text had affected their thinking. They were habituated to playing the game of school where it is the student's task to guess what in the reading would be important to the teacher, not what in the reading was important to them.

Once they began to give themselves permission to hear their own voices, it was cause for new excitement about learning. This was best expressed in these phrases from one student's responses "Another thing I'm learning is how to be excited about my own thinking...l feel myself watching for how the words are going to affect me as I read them..." (p. 53).

23 Here are the test results. Students in Group 1 who completed four MRAs throughout the course averaged $90 \%$ on Test \# 1, 91\% on Test \# 2, and $92 \%$ on Test \# 3. Students in Group 2 averaged $76 \%$ on Test \# 1,77\% on Test \# 2, and $78 \%$ on Test \# 3. Obviously, since Group 1 consisted of a small section of honors students and Group 2 consisted of a large section of general students, we cannot attribute the significance in higher test scores to the implementation of the MRAs alone. Thus, I am looking forward to teaching two similar sections on Introduction to Philosophy in order to gather more reliable data.

${ }^{24}$ Two students offered no response.

\section{References}

Buckman, K. (2007, Fall). What counts as assessment in the $21^{\text {st }}$ century? Thought and Action: The NEA Higher Education Journal 23. Retrieved May 29, 2009 from http://www2.nea.org/he/heta07/ima ges/2007pg29. pdf.

Falk, A. (2008). Assessing assessment. Johns Hopkins University Arts \& Sciences Magazine Online, 6 (1). Retreived March 13, 2009 from

http://krieger2.jhu.edu/magazine/f08 /view.html.

Gadamer, H. (1989). Truth and method. (J. Weinsheimer and Donald G. Marshall, Trans.). London: Continuum. (Original work published 1960.)

Gallagher, S. (1992). Hermeneutics and education. New York: State University of New York Press.
Gallagher, S., and Zahavi, D. (2008). The phenomenological mind: An introduction to philosophy of mind and cognitive science. New York: Routledge.

Heidegger, M. (1962). Being and time. (J. Macquarrie and Edward Robinson, Trans.). New York: Harper $\&$ Row Publishers. (Original work published 1927.)

Husserl, E. (1962). Ideas: General introduction to pure phenomenology. (W. B. Gidson, Trans.). New York: Macmillan Publishing Company. (Original work published 1931.)

Husserl, E. (2001). Logical investigations. Volume 2. ( $\mathrm{J}$. N. Findlay, Trans.). London: Routledge. (Original work published 1901.)

Kallack, D. (1989, July/October). The speakerly teacher: Socrates and writing. Metaphilosophy 20 (3\&4): 341-346. 
Moran, D. (2000). Introduction to phenomenology. London: Routledge.

Obama, B. (2009). Our kids, our future. Retreived March 13, 2009 from

http://www.usatoday.com/news/pdf/ obama-on-education-nov-202007.pdf.

Obama, B. (2009). Remarks by the President to the Hispanic Chamber of Commerce on a Complete and Competitive American Education. Retreived March 10, 2009 from http://www. whitehouse.gov/the_pres s_office/Remarks- of-the-Presidentto-the-United-States-HispanicChamber-of-Commerce/.

Plato. (2003). The last days of Socrates. (H. Tarrant, Ed. and H. Tredennick, Trans.). New York: Penguin Classics. (Original work written ca. 395 BC.)

Ricoeur, P. (1981). Hermeneutics and the human sciences. ( $\mathrm{J}$. B.

Thompson, Ed. and Trans.). Cambridge: Cambridge University Press. (Original work published 19701979.)
Ricouer, P. (1974). Political and social essays. (D. Stewart and J. Bien, Eds.). Athens: Ohio University Press.

Rosenblatt, L. M. (1978). Literature as exploration ( $4^{\text {th }}$ ed.). New York: The Modern Language Association of America.

Rosenblatt, L. M. (1978). The reader, the text, the poem: The transactional theory of the literary work.

Carbondale, Illinois: Southern Illinois University Press.

Schrader, D. (Ed.) (2008, January). Proceedings and Addresses of the American Philosophical Association 81(3).

Solloway, S. G. \& Brooks, N. J. (2004, Summer). Philosophical hermeneutics and assessment: Discussions of assessment for the sake of wholeness. Journal of Thought 39 (2): 43-60.

Walvoord, B. E. \& Anderson, V.J . (1998). Effective grading: A tool for learning and assessment. San Francisco, CA: Jossey-Bass.

Michael Strawser is an Assistant Professor of Philosophy at the University of Central Florida, where he was awarded the Excellence in Undergraduate Teaching Award (2007) and Teaching Incentive Program Award (2007). He received his Ph.D. in philosophy in 1993 from the Florida State University. His published works focus on collaborative learning, Kierkegaard, and Continental Philosophy (both modern and contemporary), and the Philosophy of Religion. He is co-editor of the online journal Florida Philosophical Review. 